\title{
Development of communication, self and emotions in childhood: contributions from the relational and dialogical perspectives ${ }^{1}$
}

\section{Desenvolvimento da comunicação, identidade e emoções na infância: contribuições das perspectivas relacional e dialógica}

\author{
Andrea Garvey ${ }^{2}$ \\ Micheline Silva ${ }^{3}$
}

\begin{abstract}
The present paper shares some reflections on the implication of conceptualizing the development of communication, self and emotions as a relational and dialogical process. It is our contention that the analysis of self, emotions and communication cannot be divorced from one another. We view emotions as relational and dialogical experiences lived in bodies that co-exist in relation to other bodies, thereby fostering the development of a differentiated, yet connected, sense of self, starting during infancy and unfolding throughout childhood.
\end{abstract}

Keywords: emotions; self; communication; dialogical perspective; selforganization.

1 Part of this work has been previously published elsewhere. See Garvey and Fogel (2007) and Garvey and Fogel (2008).

2 Ph.D. in Developmental Psychology from the University of Utah, Utah, U.S.A. Professor American River College Department of Psychology 4700 College Oak Drive Sacramento, CA 9584. 1 (916) 484-8398. Email: GarveyA@arc.losrios.edu. Web address: http://ic.arc.losrios.edu/ garveya/ bio.htm.

3 Ph.D. in Developmental Psychology from Clark University, MA, U.S.A. Psychology Faculty Nationwide Children's Hospital Child Development Center (CDC). 187 West Schrock Road. Westerville, OH 43081. 1 (614) 355-8315. Email: micheline.silva@nationwidechidrens.org. 


\section{RESUMO}

O presente trabalho partilha algumas reflexões acerca das implicações de se conceitualizar o desenvolvimento das emoções, do "self" e da comunicação como processos dialógicos e relacionais. Propõe-se que a análise das emoções, do "self" e da comunicação não divorciem tais elementos. As emoções são concebidas, aqui, como experiências relacionais e dialógicas vivenciadas em corpos que coexistem em relação a outros corpos, facilitando assim o desenvolvimento de um "self” diferenciado, mas, ao mesmo tempo, conectado.

Palavras-chave: emoções; "self”; comunicação; processos dialógicos; auto-organização.

\section{Introduction}

This paper is grounded on the premise that emotions and self emerge through communication processes. Emotions are viewed as relational and emerging through dialogical experiences lived in bodies, bodies that co-regulate their movements with the movements of others (GARVEY; FOGEL, 2007). Furthermore, emotions help punctuate one's self position in the dynamic flow of communication (FOGEL, 2001; GARVEY; FOGEL, 2008). The theoretical underpinnings of the perspective presented herein are predominantly influenced by dynamic systems theory and the work of Mikhail Bakhtin. We start by discussing dynamic systems principles relevant to our understanding of emotions. We then present a short discussion of Bakhtin's contributions to our view of self as emerging through dialogical encounters with others and with the world. We conclude with a few reflections on the implication of conceptualizing the development of communication, self and emotions as relational and emerging through dialogical processes.

\section{Emotions and Self as Developing through Communication}

As we discussed elsewhere (GARVEY; FOGEL, 2008; PANTOJA, 2001), the linguistic connotation of the term emotion is deeply rooted in the tradition of viewing (and studying) emotions as internal, discrete states somewhat "con- 
tained" in the individual and expressed outwardly (EKMAN; FRIESEN, 1975; IZARD, 1997). Similarly, the notion of selfhood finds its popularity in trait theories in which self development is often viewed as an individual endeavor, or, at best, a process involving an unidirectional movement of internalizing culture (VAN MEIJL, 2008). These mainstream conceptualizations of emotions and self have something in common: a dichotomous, container-like view of self and others. In the flow of everyday life, emotions and self dynamically evolve in relational contexts through dialogical pushes-and-pulls of being together and apart.

\section{The Principle of Self-Organization}

Dynamic systems theory strongly relies on the principle of self-organization as central in facilitating one's understanding of the emergent nature of development (FOGEL et al., 1992; GRANIC, 2000; LEWIS, 1995; 2004; LEWIS; TODD, 2005; LIABLE; THOMPSON, 2000; MESSINGER; DICKSON; FOGEL, 1997; 1999; PANTOJA; NELSON-GOENS; FOGEL, 2001; VAN GEERT, 2003). Self-organization is a continuous and spontaneous process of mutual influence among the system's components. It is said that patterned activity within a system emerges through the cooperation of the various components of that system, that is, patterns self-organize. To self-organize is "to form intricate patterns from interactions among simpler parts, without prespecified blueprints" (LIABLE; THOMPSON, 2000, p. 299). A key contribution of the principle of self-organization is the notion that an a priori (or latent) order does not exist. For instance, the patterned facial configurations of joy or sadness are conceptualized as self-organizing through the mutual cooperation of the various muscles of the face, rather than reflecting a "blueprint" for joy or sadness. Many other implications of dynamic systems theory for the study of emotions exist, but such discussion is beyond the scope of this paper (see CAMRAS, 1991; FOGEL et al., 1997; LEWIS, 1995, for more details). We focus instead on how the principle of self-organization helps us conceptualize the emergent nature of emotions.

Similarly, a child's emotional experiences of joy or fear when facing particular situations (e.g., a sudden noise produced by an activated toy) cannot be understood as a preprogrammed, predictable, and immutable internal reaction. Instead, it reflects a dynamic unfolding of meaning construction as the child and those around her dynamically regulate their bodily experiences and actions to one another and to the situation, mutually constructing meanings and emotional configurations to that particular situation. For example, as the child activates a toy and it produces a sudden noise, the child may immediately frown and move 
her body away from the toy as she gazes at her mother. As the mother simultaneously looks at the child and laughs saying: "Oops! That was funny!", the child may smile back to the mother, look back to the toy and activate it again, this time timidly smiling and looking back and forth between the toy and her mother. Therefore, emotions are relational because they self-organize in communication contexts. As stated by Lewis and Todd (2005) in their discussion of emotions and cognition:

"Emotion theorists who have taken a dynamic systems approach (FOGEL, 1993; LEWIS, 1995; 1996; SCHERER, 2000) view emotions as evolving wholes, rather than end-points in a cognitive computation or starting points in the production of a cognitive bias. Emotional wholes are seen as cohering in real time through the interaction of many constituent processes, and it is the synchronization of these processes, as well as the properties of the whole, that becomes the focus of investigation." (p. 215).

It is important to note that the contention of emotions as relational does not implicate that individuals become "diluted" in the relationship. Each individual's emotional experience is situated in a specific body, occupying a unique location in relation to another person's body. In other words, emotions include facial and bodily movements that are continuously situated within relational scenarios (PANTOJA, 2001). This contention of being with others but at the same time apart from others provides an important link with Bakhtin's contribution to our understanding of self and emotions.

\section{Mikhail Bakhtin: Self in Dialogue}

As we discussed elsewhere (GARVEY; FOGEL, 2007), Bakhtin offers a perspective of selfhood that is contrasted with the predominant dualistic view of self-other of the early 20th century. In his philosophy of dialogue, Bakhtin emphasizes heteregeneity and situatedness of the self - a revolutionary view at the time and, to a certain extent, still today (HOLQUIST, 1994). Deeply concerned about how individuals in the very act of speaking situate (or position) themselves in relation to others, Bakhtin's philosophy of dialogue is not to be simplified to analyses of interpersonal discourse. Instead, dialogism represents a worldview in which one's existence, one's sense of selfhood, cannot be divorced from the experiences of being with others.

According to Bakhtin's dialogical approach to self (BAKHTIN, 1973; $1978 ; 1986 ; 1993)$, "self" or a "sense of self" emerges and develops through the process of assuming a certain position (or positions) vis-à-vis different situations and/or social others. In this sense, the term "dialogue" should not be understood only as concrete face-to-face verbal communications with others. 
Bakhtin used the term "dialogue" in a broader manner, as a metaphor that conveys the encounter of the individual with his/her outside/external world, through which both the individual and the world are transformed. As social and cultural beings, we have to constantly assume a specific position (or positions) - delimitate who we are (our individuality or self) - within our social environment. It goes beyond our position/location in physical and spatial terms; it involves our psychological and existential position in the world as well. This process of self-positioning takes place precisely through the dialogues we establish with our social world (HOLQUIST, 1990). As Michael Holquist (1994, p. 18-19) put: "In dialogism, the very capacity to have consciousness is based on otherness. [...] More accurately, it is the differential relation between a center and all that is not that center. [...] It cannot be stressed enough that for him 'self' is dialogic, a relation.".

This view of selfhood lived as heterogeneous and situated in dialogue does not negate self as uniquely distinct from others (HERMANS, 1996; 1997). Bakhtin often wrote about the lively experiences of selfhood as a "unique and unified event of being," a being whose unique body, whose unique existence is lived through and in dialogue with others. But how does this uniqueness emerge through dialogue? In dialogue, self and other simultaneously occupy different bodies located in different spaces, thereby circumscribing each individual's position (and emotions) in relation to one another.

Let us consider an occurrence commonly observed in the lives of many young infants interacting with their caregivers. As an infant moves his arm toward an object that is out of his reach, the completion (or not) of that movement will depend on whether or not that object is placed within his reach by another person (say, his mother). In this case, the infant's joyous bodily experiences of successfully reaching the object depends on the motor support provided by his mother as she places the object closer to her infant's reach. In this example, the dynamics of two feeling bodies, simultaneously positioned in two different spatial locations, co-participating in the emotional experiences of successfully or unsuccessfully reaching an object is observed. Therefore, by simultaneously occupying different bodies that are feeling different sensations in relation to one another, mother and infant dialogically circumscribe each other's self position and, in a way, each other's emotions. Multiple encounters of similar nature that happen over time between infants and their primary caregivers constitute the perfect ground for the development of an intrinsically relational and dialogical sense of self positioning, in which emotions, self, and communication are mutually being constructed as part of a dynamically organized system. 


\section{Putting It All Together}

Emotions and self are conceived of as co-evolving through everyday dialogical movements. Emotions are also intrinsic to one's self development in that they highlight a person's self position in relation to others. Through dialogue, the body will tune into various emotional experiences such as openness or closeness toward others, connection or disconnection from others, and so on, a process called affective resonance (SCHORE, 2001).

Conceptualizing emotions and self as relational processes that emerge through dialogical activities requires a shift in the psychological unit of analysis from the individual to the individual in relation. Many contemporary developmental psychologists (FOGEL, 1993; LYRA, 2000; LYRA; WINEGAR, 1997) have written extensively about the importance of examining the individual in relationships. This methodological movement reflects not only a shift in the way contemporary psychologists study development but also how development is conceptualized. Specifically, developmental changes are viewed (and studied) as emerging in the flow of a person's dialogue with others, whether these dialogical exchanges are predominantly linguistically-based or bodily-based.

In our work (FOGEL; GARVEY, 2007; GARVEY; FOGEL, 2007; 2008; PANTOJA, 2001), we have discussed how mother-infant dyads, through the process of relationally transforming the landscape of their communication, co-create emotional patterns that foster multiple opportunities for the infant to explore his self positions in dialogue with his mother. In other words, an infant's differentiation from others is accomplished dialogically in the midst of his emotional experiences of relating with others. While engaged in various dialogical formats (we call "frames"), mother and infant simultaneously occupy different bodies located in different spaces - bodies that moved and changed in relation one another. For a more in-depth discussion of the methodological contributions of "frames", see Garvey and Fogel (2008).

Using the same conceptual framework to the investigation of coping and emotional adjustment to leukemia and bone marrow transplant in school age children, Silva $(2004 ; 2005)$ explored how the emotional experiences associated with the illness and treatment are intrinsically and dynamically connected to the children's recalibration of their dialogically constructed sense of self. In order words, coping and emotional adjustment are discussed as a dynamic process of the child's re-positioning of herself by constructing new meanings and emotional configurations through dialogical interactions with significant others, vis-à-vis the unfolding of stressful situations brought about by the illness and its treatment. 


\section{Concluding Remarks}

Influenced by dynamic systems theory and the notion of dialogism from Mikail Bahktin, we emphasized that emotions, self and communication are inseparable processes that emerge and flow together in the day-to-day occurrences of dialogical partners. Furthermore, emotions serve to punctuate, from the flow of communication, the different positions each dialogical partner occupies. It is important to highlight that a relational and dialogical perspective of emotions and self does not deny that individuals feel and perceive their part in communication processes as "their own" contribution. Instead, this dialogical perspective capitalizes an inevitable characteristic of "being": a "being-in-relation." As our everyday experiences remind us, relationships open us up to a multiplicity of possibilities, including self possibilities, while at the same time fostering a sense of emotional connection with (or disconnection from) others and the world.

The process of mutual development of emotions, self, and communication through everyday dialogical movements can be identified since very early in life, as the infants and their primary caregivers start to engage in dynamic episodes of co-regulation of their body sensations and actions while embedded in different contexts. During these dialogical encounters the child is impelled to assume specific positions vis-à-vis particular others, events or situations, and, over time, she starts to construct a historical sense of who she is (or a self-biography). This historically and dialogically constructed sense of self becomes a ground that guides the child's actions, thoughts, and emotions when relating to different others and situations. At the same time, emotions foster and regulate the new dialogical encounters between the child and the world, leading to opportunities for the child to develop new self-positioning and sense of self.

This conceptual and methodological shift from "the individual" to the "individual in relation" as the unit of analysis appears to provide fruitful tools for the future investigation of child development not only under "ordinary" everyday circumstances, but also under "out of the ordinary" circumstances such as when the child faces life threatening illnesses or other major emotionally stressful experiences. 


\section{REFERENCES}

BAKHTIN, M. Problems of Dostoevsky's poetics. Ann Arbor: Ardis, 1973.

. The formal method in literary scholarship: A critical introduction to sociological poetics. Cambridge: Harvard University Press, 1978.

1986.

. Speech genres and other late essays. Austin: University of Texas Press,

. Toward a Philosophy of the Act. Austin: University of Texas Press, 1993.

CAMRAS, L. A. Conceptualizing early infant affect. In: STRONGMAN, K. (Org.). International review of studies on emotion. New York: Wiley, 1991. p. 16-28.

EKMAN, P.; FRIESEN, W. Unmasking the face. Englewood Cliffs: Prentice-Hall, 1975.

Press, 1978.

. Manual for the facial affect coding system. Palo Alto: Consulting Psychologist

FOGEL, A. Developing through relationships. Chicago: University of Chicago, 1993.

. A relational perspective on the development of self and emotion. In: BOSMA, H. A.; KUNNEN, E. S. (Orgs.). Identity and emotions: development through selforganization. New York: Cambridge University Press, 2001.

FOGEL, A. et al. Communicative dynamics of emotion. In: BARRETT, K.C. (Org.). The communication of emotion: current research from diverse perspectives. San Francisco: Jossey-Bass Inc., 1997. p. 5-24.

FOGEL, A.; GARVEY, A.; HSU, H.; WEST-STROMING, D. Change processes in relationships: a relational-historical research approach. New York: Cambridge University Press, 2006.

FOGEL, A.; GARVEY, A. Alive communication. Infant Behavior and Development, n. 30, p. 251-257, 2007.

GARVEY, A.; FOGEL, A. Dialogical change processes, emotions, and the early emergence of self. International Journal for Dialogical Science, v. 2, n. 1, p. 51-76, 2007.

. Emotions and communication as a dynamic developmental system. Espacotiempo, n. 2, p. 62-73. 2008. 
GRANIC, I. The self-organization of parent-child relations: Beyond bidirectional models. In: LEWIS, M.; GRANIC, I. (Orgs.). Emotion, Development and SelfOrganization: dynamic systems approaches to emotional development. New York: Cambridge University Press, 2000. p. 267-348.

HERMANS, H. J. M. Voicing the self: From information processing to dialogical interchange. Psychological Bulletin, v. 119, n. 1, p. 31-50, 1996.

. Dialogue shakes narrative: From temporal story line to spatial juxtaposition. Journal of Narrative and Life History, v. 7, n. 1-4, p. 387-394, 1997.

HOLQUIST, M. Dialogism: Bakhtin and his world. New York: Routledge, 1990.

. Dialogism: Bakhtin and his World. New York: Routledge, 1994.

IZARD, C. E. Emotions and facial expressions: a perspective from differential emotions theory. In: RUSSEL, J. A.; FERNANDEZ-DOLS, J. M. (Orgs.). The psychology of facial expression. New York: Cambridge University Press, 1997. p. 57-77.

KELLERT, S. H. In the wake of chaos: unpredictable order in dynamical systems. Chicago: The University of Chicago Press, 1993.

LEWIS, M. Cognition-emotion feedback and the self-organization of developmental paths. Human Development, n. 38, p. 71-102, 1995.

LIABLE, D.; THOMPSON, R. Attachment and self-organization. In: LEWIS, M.; GRANIC, I. (Orgs.). Emotion, Development and Self-Organization: dynamic systems approaches to emotional development. New York: Cambridge University Press, 2000. p. 298-323.

LYRA, M. C. D. P. Desenvolvimento como processo de mudança em um sistema de relações historicamente construído: contribuições do estudo da comunicação no início da vida. Reflexão e Crítica, v. 13, n. 2, p. 257-268, 2000.

LYRA, M. C. D. P.; WINEGAR, L. T. Processual dynamics of interaction through time: adult-child interactions and process of development. In: FOGEL, A.; LYRA, M. C. D. P.; VALSINER, J. (Orgs.). Dynamics and Indeterminism in Developmental and Social Processes. Hillsdale: LEA, 1997. p. 93-109.

PANTOJA, A. P. F. A narrative-developmental approach to early emotions. Forum Qualitative Sozialforschung/Forum: qualitative social research [On-line Journal], v. 2, n. 3. Disponível em: $<$ http://www.qualitative-research.net/fqs-texte/3-01/3-01 pantoja-e. $\mathrm{htm}>$. Acesso em: 2001.

PANTOJA, A. P. F.; NELSON-GOENS, G. C.; FOGEL, A. A dynamical systems approach to the study of early emotional development in the context of mother-infant communication. 
In: KALVERBOER, A. F.; GRAMSBERGEN, A. (Orgs.). Handbook of brain and behaviour in human development. Norwell: Kluwer Academic Publishers, 2001. p. 901-920.

SCHORE, A. Effects of a secure attachment on right brain development, affect regulation, and infant mental health. Infant Mental Health Journal, v. 22, n. 1-2, p. 7-66, 2001.

SILVA, M. A longitudinal study of two children undergoing stem cell transplant: analyzing coping as a process of adaptive self-regulation. Unpublished Doctoral Dissertation. Clark University, 2004.

. Generic disease and particular lives: a systemic and dynamic approach to childhood cancer. In: BIBACE, R.; LAIRD, J. D.; NOLLER, K. L.; VALSINER, J. (Orgs.). Science and Medicine in Dialogue: thinking through particulars and universals. Westport: Praeger, 2005.

THELEN, E.; ULRICH, B. D. Hidden skills: a dynamic systems analysis of treadmill stepping during the first year. Monographs of the Society for Research in Child Development, v. 56, n. 1, 1991.

VAN GEERT, P. Dynamic systems approaches and modeling of developmental processes. In: VALSINER, J.; CONNOLLY, K. J. (Orgs.). Handbook of Developmental Psychology. Thousand Oaks: Sage Publications, 2003. p. 640-672.

VAN MEIJL, T. Culture and identity in anthropology: reflections on "unity" and "uncertainty" in the dialogical self. International Journal for Dialogical Science, v. 3, n. 1, p. 165-190, 2008.

Texto recebido em 19 de novembro de 2009.

Texto aprovado em 12 de janeiro de 2010. 